\title{
Contrasting multi-taxa diversity patterns between abandoned and non- intensively managed forests in the southern Dolomites
}

\author{
Tommaso Sitzia ${ }^{(1)}$, \\ Thomas Campagnaro ${ }^{(1)}$, \\ Matteo Dainese ${ }^{(1)}$, \\ Michele Cassol (2), \\ Marialuisa Dal Cortivo( ${ }^{(3)}$, \\ Enzo Gatti ${ }^{(3)}$, \\ Fabio Padovan ${ }^{(4)}$, \\ Monica Sommacal (3), \\ Juri Nascimbene ${ }^{(5)}$
}

\begin{abstract}
The abandonment of silvicultural activities can lead to changes in species richness and composition of biological communities, when compared to those found in managed forests. The aim of this study was to compare the multi-taxonomical diversity of two mature silver fir-beech-spruce forests in the southern Dolomites (Italy), corresponding to the European Union habitat type $\mathbf{9 1 3 0 .}$ The two sites share similar ecological and structural characteristics, but differ in their recent management histories. In the last $\mathbf{5 0}$ years, one site underwent non-intensive management, while the other was left unmanaged and was included in a forest reserve. The species richness and composition of eight taxa were surveyed in the two sites between 2009 and 2011. The difference in mean species richness between the two forest management types was tested through permutation tests, while differences in species composition were tested by principal coordinates analysis and the permutational multivariate analysis of variance. Mean species richness of soil macrofungi, deadwood lichens, bark beetles, and longhorn beetles were significantly higher in the abandoned than in the non-intensively managed forests. Deadwood fungi and epiphytic lichens did not differ in mean species richness between the two study sites, while mean species richness of ground beetles and birds were higher in the non-intensively managed than in the abandoned forest. Significant differences in species composition between the two sites were found for all the taxa, except for longhorn beetles. These results indicate that improving forest landscape heterogeneity through the creation of a mosaic of abandoned and extensively managed forests should better fulfill the requirements of ecologically different taxa.
\end{abstract}

Keywords: Asperulo-Fagetum, Forestry Abandonment, Biodiversity Conservation, Selection Cutting, Natura 2000, Silver Fir

\section{Introduction}

Intensive forest management practices are frequently a major driver of biodiversity loss worldwide. In Europe, a large body of research has been conducted to evaluate the impact of forestry on biodiversity in European forests, and provide sciencebased guidelines for conservation. Many of these studies are related to boreal forests (Paillet et al. 2010a), and are based on com- parisons between intensively managed forests (e.g., those subjected to clearcutting) and forests managed for conservation (e.g., old-growth forests, minimal intervention forests, or stands where forestry practices have ceased in the last decades - Götmark 2013). From these studies, there is general agreement regarding the beneficial effects of forest abandonment on biodiversity (Paillet et al. 2010a), due to the

(1) Department of Land, Environment, Agriculture and Forestry, Università degli Studi di Padova, v.le dell'Università 16, I-35020 Legnaro, Padova (Italy); (2) Cassol \& Scariot Forest and Wildlife Professionals, v. Stadio 18, I-32036 Sedico, Belluno (Italy); (3) Raggruppamento Carabinieri Biodiversità - Reparto Biodiversità di Belluno, v. Gregorio XVI 8, I-32100 Belluno (Italy); (4) Mycologist, v. Mier 73, I-32100 Belluno (Italy); (5) Department of Biological, Geological and Environmental Sciences, University of Bologna, v. Irnerio 42, I-40126, Bologna (Italy)

\section{@ Tommaso Sitzia (tommaso.sitzia@unipd.it)}

Received: Jul 28, 2016 - Accepted: Jun 30, 2017

Citation: Sitzia T, Campagnaro T, Dainese M, Cassol M, Dal Cortivo M, Gatti E, Padovan F, Sommacal M, Nascimbene J (2017). Contrasting multi-taxa diversity patterns between abandoned and non-intensively managed forests in the southern Dolomites. iForest 10: 845850. - doi: 10.3832/ifor2181-010 [online 2017-10-26]

Communicated by: Matteo Garbarino development of habitat attributes which are more similar to those of old-growth forests (Vandekerkhove et al. 2009).

However, the positive effects of forest abandonment may not be consistent across taxa, especially when the transitions of non-intensively managed forests are considered. According to the intermediate disturbance hypothesis (Grime 1973, Connell 1978), higher species diversity may be expected under non-intensive forest management systems where disturbances occur at intermediate frequencies (e.g., selection systems), than would be expected in an entirely unmanaged forest (Torras \& Saura 2008).

This framework could apply to several forests in the European Alps, which have been non-intensively managed for both timber production and multiple ecosystem services since the second half of the $20^{\text {th }}$ century (Piussi \& Farrell 2000). For example, in Alpine larch (Larix decidua Mill.) woodlands, forest abandonment could be detrimental for species which benefit from intermediate disturbance regimes (Nascimbene et al. 2014). However, despite the fact that alpine forests are important conservation habitats in Europe, with many included in the Natura 2000 network, multiple taxa 
Tab. 1 - Mean ( \pm standard deviation) structural parameters showing significant differences $(P<0.01)$ between sample sites at the non-intensively managed and the abandoned forests. P-values were obtained using a linear mixed model (forest management as a fixed factor, plot as a random factor) with a restricted maximum likelihood (REML) approach.

\begin{tabular}{llcc}
\hline Variable & Type & $\begin{array}{c}\text { Non-intensively } \\
\text { managed }\end{array}$ & Abandoned \\
\hline Beech crown cover $(\%)$ & - & $28.6 \pm 19.7$ & $55.6 \pm 13.8$ \\
Coarse woody debris & Stumps & $23.0 \pm 9.9$ & $6.0 \pm 3.5$ \\
$\left(\mathrm{~m}^{3} \mathrm{ha}^{-1}\right)$ & Snags & $1.7 \pm 3.4$ & $14.1 \pm 8.5$ \\
\hline
\end{tabular}

biodiversity effects of forest abandonment as compared to non-intensive forest management are not well understood.

Assessing the response of multiple taxa to forest management could provide more robust information on forest biodiversity patterns and drivers compared to focusing only on a single taxon (Lawton et al. 1998, Vessby et al. 2002, Fattorini et al. 2011). For example, the use of a multi-taxon approach is the basis for elucidating the potential co-variation among organisms exploiting different substrates (e.g., soil, dead wood, tree bark) and occupying different trophic levels (Blasi et al. 2010). Information on species diversity patterns for multiple taxa is therefore crucial for the assessment of conservation priorities (Paillet et al. 2010b) and of surrogate taxa for the representation of biodiversity (Lewandoski et al. 2010, Santi et al. 2010, Gioria et al. 2011). The need for these data is currently one of the key challenges in forestry research (Blasi et al. 2010, Gao et al. 2015).

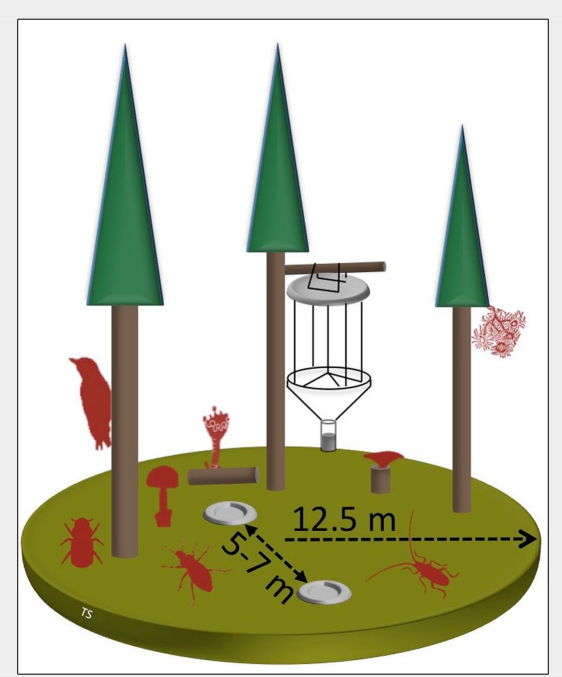

Fig. 1 - Schematic diagram of the sampling plots, where the silhouettes of animals represent the eight taxonomic groups surveyed. Beetles were surveyed with two pitfall and one window trap, while the other taxa were surveyed by counting the species occurring inside the sampling plot, on the ground, living trees, deadwood, or acoustic detection (images with different scales).
Currently, the knowledge gap regarding the effects of forest management on multiple taxa is related to two main issues: (a) the complexity in controlling potential confounding factors, such as site conditions, landscape context, past management history (Sitzia et al. 2012), that hinders the development of studies with adequate replication for general statistical inference (Paillet et al. 2010b); and (b) the cost of performing multi-taxon studies that simultaneously evaluate the response of different taxa which have a range of ecological re-

In this study, we tested the hypothesis that the effects of forest abandonment on biodiversity are consistent and positive across taxa in non-intensively managed forests. We surveyed eight taxa in mountain forests dominated by silver fir (Abies alba Mill.), beech (Fagus sylvatica L.), and Norway spruce (Picea abies [L.] H. Karst.). We compared the diversity patterns between two neighboring watersheds in the Italian Alps, one of which has been subjected to forest abandonment for 50 years, and the second which has been non-intensively managed by selective logging. To mitigate the impact of pseudo-replication in our experimental design, the forests of the two watersheds were characterized by matched phytosociological, past management history, climatic, and topographic conditions (Sitzia et al. 2012). The eight taxa were selected to cover a wide range of resource uses and substrates, in terms of soils, deadwood and epiphytic organisms, photosynthetic organisms, decomposers, and predators.

\section{Methods}

\section{Study areas}

The study was conducted in a mountain forest district of the southern Dolomites, in the eastern Italian Alps. The mean annual temperature is $7.2^{\circ} \mathrm{C}$, and the mean annual precipitation ranges from 1300 to 1500 $\mathrm{mm}$, mainly concentrated in May-June and October-November. The most common forest soils are cambisols (ARPAV 2005), and the bedrock consists of calcareous and dolomitic materials (Regione Veneto 2010).

The focus of this research was in the adjacent watersheds of Tovanella $\left(46^{\circ} 18^{\prime} \mathrm{N}, 12^{\circ}\right.$ $\left.18^{\prime} \mathrm{E}\right)$ and Cajada $\left(46^{\circ} 14^{\prime} \mathrm{N}, 12^{\circ} 14^{\prime} \mathrm{E}\right)$. Both watersheds are approximately 1040 ha in quirements (Paillet et al. 2010a). size, with elevations ranging from 550 to $2500 \mathrm{~m}$ a.s.l., and have a similar history of forest management, but are currently subjected to contrasting forest management regimes (Sitzia et al. 2012). Both forests have been heavily logged in the last century. From 1943 to 1953 , the ratio of yield to increment was up to $150 \%$. This resulted in a very low growing stock of less than $200 \mathrm{~m}^{3} \mathrm{ha}^{-1}$, with a low density of large trees (Susmel 1958, Lazzarini 1999).

In the Tovanella watershed, both forestry and grazing ceased in 1957 (Susmel 1958), and the site has been part of a nature reserve since 1971. In Cajada watershed, nonintensive logging is conducted by group-selection, with coupe sizes not larger than $1000 \mathrm{~m}^{2}$, and grazing is not admitted inside forests. Based on the data available for a forest compartment adjacent to the surveyed plots, the mean annual harvest in the Cajada watershed in the period 19912003 (prior to the survey time) has been 1.7 $\mathrm{m}^{3} \mathrm{ha}^{-1}$, which corresponds to $0.6 \%$ of the growing stock and $33 \%$ of the annual increment (Andrich 2004). Due to these different management regimes, the forests of the two watersheds differ in some structural parameters, which are summarized in Tab. 1. Both watersheds are currently included in Natura 2000 sites (Tovanella: site IT3230031, 8845 ha, and IT3230089, 70,397 ha; Cajada: site IT3230083, 31,383 ha), and are therefore aimed at biodiversity conservation according to the Habitats Directive (92/43/EEC).

\section{Sampling design and species data collection}

In each watershed, ten sampling units (Fig. 1) were randomly selected and permanently marked in the field. Each sample was located within a mature mixed silver fir-beech-Norway spruce forest (EU habitat type 9130) with a slope of less than $26^{\circ}$ (Lasen et al. 2008, Ente Parco Nazionale delle Dolomiti Bellunesi 2009). At each sample location, a $12.5 \mathrm{~m}$ radius circular plot $\left(491 \mathrm{~m}^{2}\right)$ was established, with a minimum distance of $200 \mathrm{~m}$ between each plot. The average altitude of the plots in Cajada was $1221 \pm 103 \mathrm{~m}$ a.s.l., with aspects ranging from NNE to $S$. The average altitude of plots in Tovanella was $1228 \pm 43 \mathrm{~m}$ a.s.l, all with $\mathrm{N}$ aspect. Previous analyses of the vegetation units based on regional phytosociological classification confirmed that the forest stands of the two watersheds represent the same forest type (Sitzia et al. 2012). This equivalence is fundamental, given that different forest types may host different communities with different species richness and composition.

Between 2009 and 2011, we surveyed the occurrence of species belonging to eight taxa at the center of the $12.5 \mathrm{~m}$ radius circular plots. The eight taxa surveyed were: (a) deadwood macrofungi; (b) soil macrofungi; (c) epiphytic lichens; (d) deadwood lichens; (e) bark beetles (Scolytinae); (f) longhorn beetles (Cerambycidae); 
ground beetles (Carabidae); and ( $h$ ) bird species. Further details on the sampling units and recording methods used for stand structure are available in Sitzia et al. (2012).

In 2009 and 2010, the occurrence of fruiting bodies of deadwood and soil macrofungi in each plot were recorded in August, September, and October. Each survey was carried out during a similar time-span to improve data comparability between plots. Species that were not directly identified in the field were collected for later identification in the laboratory, and specimens were stored in permanent collections.

The occurrence of all epiphytic lichens present from the tree-base up to $2 \mathrm{~m}$ height were assessed in 2009 for all individual silver fir, Norway spruce, and beech trees. Deadwood lichens were surveyed on all stumps, snags, and logs occurring in each plot (see Nascimbene et al. 2013 for further details).

Two different traps were used to assess the abundance of beetle species in the plot: two pitfall traps for ground beetles and one window trap for longhorn and bark beetles. Traps were inspected every 15 days between May and mid-October 2009 (see Sitzia et al. 2015 for further details).

Birds were surveyed twice per year during the reproductive season (end-May and June) between sunrise and 11 a.m. Each survey consisted of a 10-minute point count, preceded by 2 minutes of silence to offset the disturbance effect due to the arrival of the surveyor. All bird species which were visually or acoustically detected were noted during the point count.

Species nomenclature followed Padovan (2008), Nimis \& Martellos (2003), Sitzia et al. (2015), and Fracasso et al. (2009) for macrofungi, lichens, beetles, and birds, respectively.

\section{Statistical analysis}

Analysis to test the effect of forest management on species diversity was carried out at the plot-level for (a) mean species richness and (b) species composition (presence-absence data) for each taxon. Differences in mean species richness were tested using a Fisher-Pitman permutation test (Berry \& Mielke 2002), and significant findings were further tested using a Monte Carlo randomization test on means, based on 9999 combinations (Neuhäuser \& Manly 2004, Torsten et al. 2016). Principal coordinates analysis based on a Sørensen's dissimilarity matrix and a permutational multivariate analysis of variance (PERMANOVA based on 9999 permutations Anderson 2001) were used to test for differences in species composition between the two forest management types. All analyses were performed using the $\mathrm{R}$ statistical software version 3.0.2 ( $R$ Development Core Team 2015), with the Fisher-Pitman permutation test performed using the "oneway_test" function in the "coin" package (Torsten et al. 2008); and the PERMANOVA analysis conducted using the "adonis" function in the "vegan" package (Oksanen et al. 2015).
Tab. 2 - Total number of species in the 10 sampling plots from each forest watershed.

\begin{tabular}{lcc}
\hline Taxon & $\begin{array}{c}\text { Non- } \\
\text { intensively } \\
\text { managed }\end{array}$ & Abandoned \\
\hline $\begin{array}{l}\text { Deadwood } \\
\text { macrofungi }\end{array}$ & 38 & 62 \\
\hline $\begin{array}{l}\text { Soil macrofungi } \\
\text { Epiphytic }\end{array}$ & 25 & 15 \\
lichens & 44 & 39 \\
\hline $\begin{array}{l}\text { Deadwood } \\
\text { lichens }\end{array}$ & 16 & 22 \\
\hline $\begin{array}{l}\text { Bark beetles } \\
\text { Longhorn } \\
\text { beetles }\end{array}$ & 12 & 17 \\
\hline $\begin{array}{l}\text { Ground beetles } \\
\text { Birds }\end{array}$ & 16 & 13 \\
\hline
\end{tabular}

\section{Results}

A total of 34 species of deadwood macrofungi, 78 soil macrofungi, 56 epiphytic lichens, 22 deadwood lichens, 17 bark beetles, 15 longhorn beetles, 19 ground beetles, and 20 birds were found in the two test watersheds (see Tab. S1 in Supplementary material for the original data used to perform the analyses). The total species richness of the 10 sampling plots for each forest watershed ( $\gamma$-diversity) is reported in Tab. 2.

The mean species richness for four taxa (soil macrofungi, deadwood lichens, bark beetles, and longhorn beetles) were significantly higher in the abandoned than in the non-intensively managed forests (Fig. 2).
Fig. 2 - Mean number of (a) deadwood macrofungi, (b) soil macrofungi, (c) epiphytic lichens, (d) deadwood lichens, (e) bark beetles, ( $f$ ) longhorn beetles, (g) ground beetles, and (h) bird species in relation to forest management (A: abandoned; M: non-intensively managed). Error bars represent the standard error. The plots report the P-values of permutation based statistical test used to test differences on mean species richness between the two forest management types. (a)
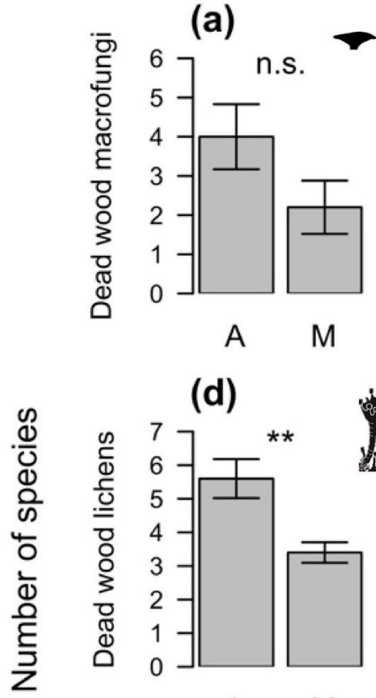

(d)
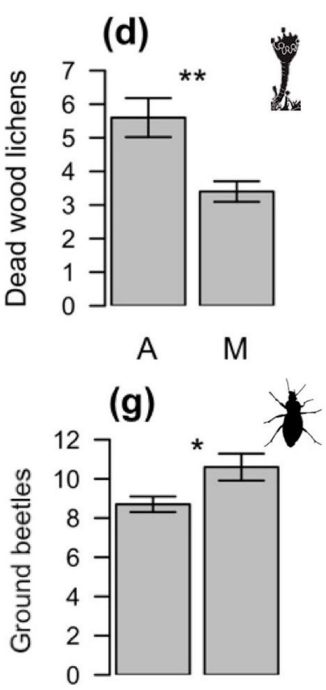

A (b)

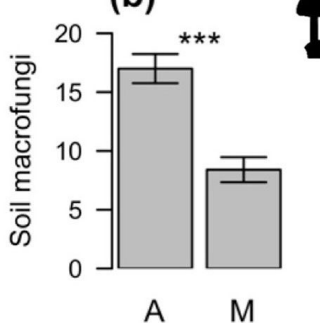

(e)

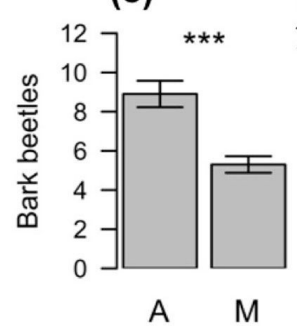

(h)

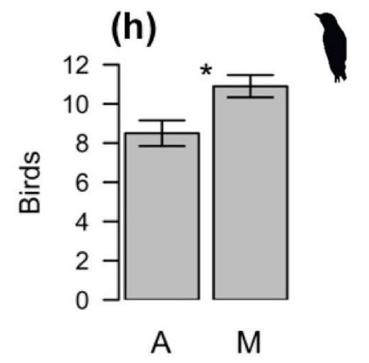

(c)

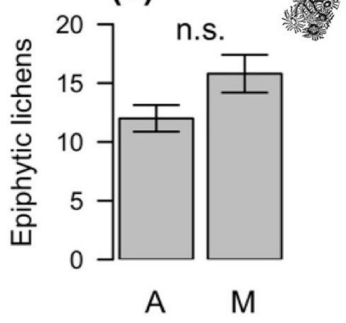

(f)

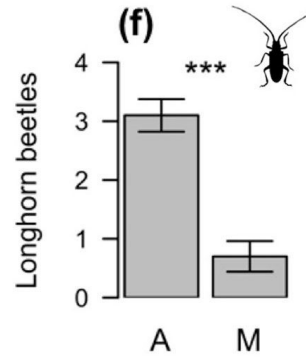



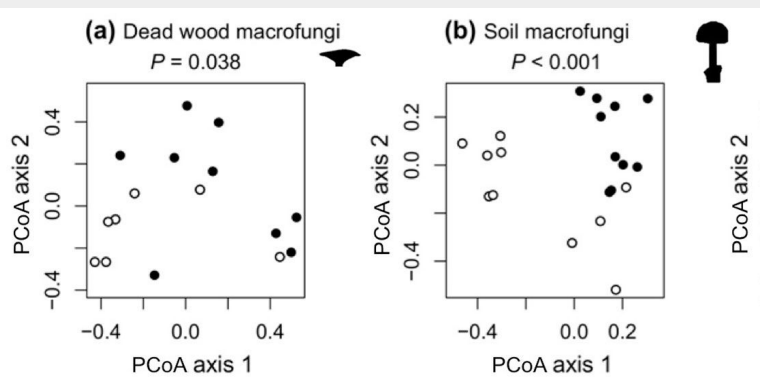

(c) Epiphytic lichens

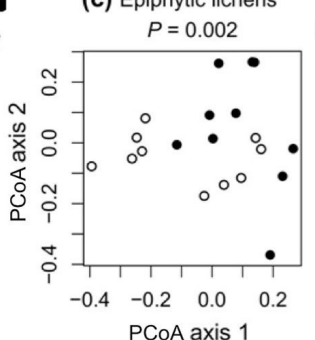

(d) Dead wood lichens
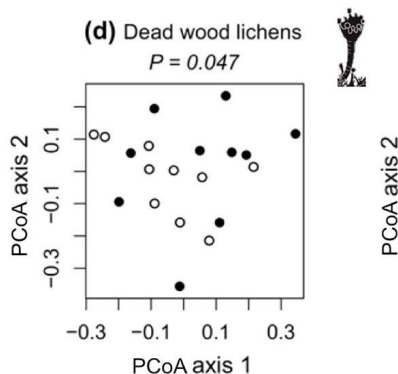

(e) Bark beetles
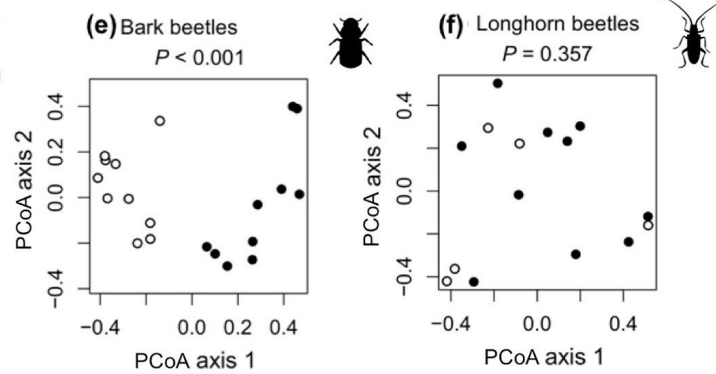

(h) Birds
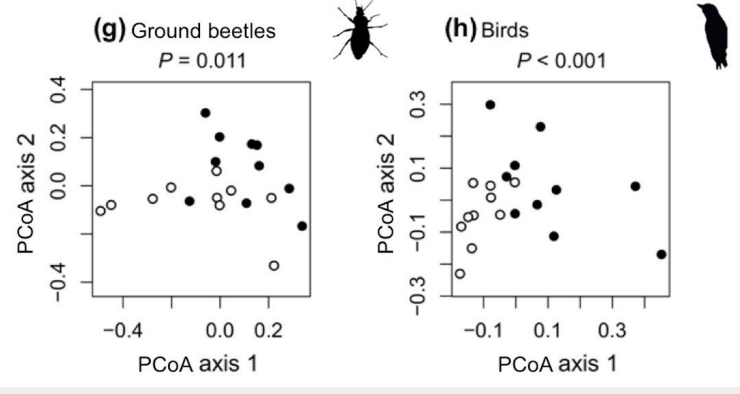

Fig. 3 - Principle coordinates analysis (Sørensen's dissimilarity matrix) of (a) deadwood macrofungi, (b) soil macrofungi, (c) epiphytic lichen, (d) deadwood lichen, (e) bark beetle, $(f)$ longhorn beetle, $(g)$ ground beetle, and (h) bird community composition. Each point represents the composition of a sampling plot (filled dots: abandoned forests; open dots: non intensively managed forests). The plots report the P-values of a PERMANOVA used to test differences in composition between the two types of forest management types. Sites are plotted only when at least one species was recorded.
No significant difference in mean species richness was found between the two management regimes for deadwood fungi or epiphytic lichens, while mean species richness for ground beetles and birds was higher in the non-intensively managed than in the abandoned forest. These findings indicate that differences in individual mean species richness do not always reflect that of total species richness (Tab. 2). However, significant differences in species composition were found between the abandoned and non-intensively managed forests for all taxa, with the exception of longhorn beetles (Fig. 3).

\section{Discussion}

The results of this study reveal contrasting diversity patterns between the abandoned and non-intensively managed forests for eight different taxa, which encompass a wide range of substrates and resource usage. These findings support the hypothesis that the biodiversity impacts of conversion from intensive forest management to forest abandonment may not be as striking and consistent across taxa as the conversion from intensive to non-intensive forestry (Paillet et al. 2010a). This may be a reflection of the fact that some species are favored by intermediate disturbance regimes (Roberts \& Gilliam 1995).

The four taxa whose mean species richness was found to be higher in abandoned forests are mainly related to deadwood (i.e., lichens, bark and longhorn beetles -
Nascimbene et al. 2013, Sitzia et al. 2015). This substrate type tends to be more abundant and diverse in abandoned forests, as these sites tend to accumulate higher amounts of logs and snags that improve the range of micro-habitats for organisms colonization. By contrast, in managed forests tree stumps are the only type of deadwood that is typically available (Nordén et al. 2004, Seidling et al. 2014). The amount and diversity of deadwood in abandoned forests are therefore likely to enhance the establishment of less common communities, which are not likely to be found in forests managed solely for timber production (Mason \& Zapponi 2015, Sabatini et al. 2016). A consistent pattern was observed in this study between lichens and bark beetles, whereas longhorn beetles showed a different pattern, in which communities similar in composition were progressively enriched by a species accumulation process, coupled with the progressive accumulation of different types of deadwood over the time since abandonment (Sitzia et al. 2015).

Higher biodiversity was observed for both birds and ground beetles in the nonintensively managed forests compared to the abandoned forests. For birds, this may reflect a negative effect on biodiversity due to canopy closure (Gil-Tena et al. 2007) associated with forestry abandonment. Moreover, forestry abandonment promotes the spontaneous reforestation of adjacent open lands and the development of forest gaps, which provide fundamental food and nesting resources for many bird species (Sitzia et al. 2014, Campagnaro et al. 2017). For ground beetles communities, our results agree with previous studies reporting that non-intensive forestry is compatible with high beetle biodiversity (Toigo et al. 2013), which may be due to the lower soil moisture levels than in abandoned forests (Sitzia et al. 2015). As it was found for other taxa in these study, the differences in mean species richness of ground beetles were not associated with differences in species composition, indicating that compositionally similar communities may evolve under different management regimes.

Interestingly, the mean species richness of epiphytic lichens and deadwood fungi did not significantly differ between non-intensively managed and abandoned forests. On the contrary, differences in species composition were detected for both taxa. For lichens, these differences may be due to gradual canopy closure, which would enhance more shade-tolerant species (Sitzia et al. 2012, Nascimbene et al. 2013). Increasing tree age would also be beneficial for lichens, due to an increase in substrate stability and availability, and changes in the chemical-physical features of the bark (Esseen et al. 1996). As with the other deadwood related organisms considered in this study, deadwood fungi showed differences in species composition that are likely related to the greater availability of different 
types of dead wood in abandoned forests, which enhances the establishment of species that cannot be found on stumps in productively managed forests (Abrego \& Salcedo 2013, Persiani et al. 2015).

We stress that the differences in diversity observed in mean species richness did not always reflect differences of total species richness. This suggests that further research and sampling is needed to elucidate the variability of species richness at the stand scale, rather than at the plot scale.

\section{Conclusions}

The contrasting diversity patterns found in this study between the eight taxa in the abandoned and non-intensively managed forests suggests that management abandonment cannot be generalized as a best practice for biodiversity conservation in mountain forests of the Alps. Rather, these findings support the hypothesis that enhancing forest landscape heterogeneity through the creation of a mosaic of abandoned and non-intensively managed forests could better fulfill the requirements of ecologically different taxa. Such an approach may enhance biodiversity conservation in forest landscapes of the Alps, at least in terms of species richness and composition.

Our results are based on a case study alone and do not allow to make a general inference on the effects of a given management regime. However, our findings can contribute to the formulation of new research hypotheses and to provide valuable data for meta-analyses, which is an increasingly used tool to explore general patterns in ecology (Davies \& Gray 2015). Moreover, the results of this study can assist in the scientific assessment of adverse effects of forest management (Sitzia et al. 2016), forest ecosystem functions mapping (Vizzarri et al. 2015), and diagnostic species selection (Carranza et al. 2012) in forest habitats. To further examine the hypotheses and findings of this study, more multitaxon investigations are needed at a variety of landscapes. Such studies should address: (a) a higher replication level, ensuring a more robust evaluation of the effect of the management regime and the exclusion of other possible factors not considered in our study (e.g., historical species distribution and landscape legacy); (b) sites abandoned for longer than 50 years, to allow for an evaluation of the consistency of the effects of abandonment found in our study across a longer time span; (c) turnover and nestedness of compositional heterogeneity ( $\beta$-diversity); and (d) an experimental approach which can better elucidate the causal relationships between management, structural features, and multi-taxon biodiversity.

\section{Acknowledgements}

M.E. Olson is acknowledged for his helpful comments on a previous version of the manuscript. This project was supported by the Italian Ministry of Agricultural, Food and Forestry Policies, State Forestry Corps (Project Managers: A. Andrighetti and D. Campedel), research agreement No. 767l 2008 (TS, Principal Investigator). We thank M. Varaschin for providing assistance to the bird survey. TC was funded by the Dept. TESAF, University of Padova (PhD grant, $29^{\text {th }}$ cycle). TS designed the methods, carried out surveys, coordinated the research team, developed and wrote the manuscript, TC played a primary role in the manuscript developing, writing and polishing, MD performed the statistical analysis, MC carried out the bird survey, EG and MS carried out the beetle surveys and coordinated the project, FP carried out the surveys of macrofungi, JN carried out the lichen surveys, played a major role in developing and writing the manuscript and collaborated to the sampling design. D. Hawtree performed the language revision of the manuscript.

\section{References}

Abrego N, Salcedo I (2013). Variety of woody debris as the factor influencing wood-inhabiting fungal richness and assemblages: is it a question of quantity or quality? Forest Ecology and Management 291: 377-385. - doi: 10.1016/j. foreco.2012.11.025

Anderson MJ (2001). A new method for nonparametric multivariate analysis of variance. Austral Ecology 26: 32-46. - doi: 10.1111/j.1442-99 93.2001.01070.pp.x

Andrich $\mathrm{O}$ (2004). Piano di riassetto forestale del Comune di Longarone, periodo di validità 20032014 [Forest plan of the Longarone Municipality, planning period 2003-2014]. Longarone, Belluno, Italy, pp. 87 and annexes. [in Italian]

ARPAV (2005). Carta dei suoli del Veneto. Legenda [Soil map of Veneto. Legend]. ARPAV, Padova, Italy, pp. 80. [in Italian]

Berry KJ, Mielke PWJ (2002). The Fisher-Pitman permutation test: an attractive alternative to the F test. Psychological Reports 90: 495-502. doi: 10.2466/pro.2002.90.2.495

Blasi C, Marchetti M, Chiavetta U, Aleffi M, Audisio P, Azzella MM, Brunialti G, Capotorti G, Del Vico E, Lattanzi E, Persiani AM, Ravera S, Tilia A, Burrascano S (2010). Multi-taxon and forest structure sampling for identification of indicators and monitoring of old-growth forest. Plant Biosystems 144: 160-170. - doi: 10.1080/11263500 903560538

Campagnaro T, Frate L, Carranza ML, Sitzia T (2017). Multi-scale analysis of alpine landscapes with different intensities of abandonment reveals similar spatial pattern changes: Implications for habitat conservation. Ecological Indicators 74: 147-159. - doi: 10.1016/j.ecolind.2016. 11.017

Carranza ML, Frate L, Paura B (2012). Structure, ecology and plant richness patterns in fragmented beech forests. Plant Ecology and Diversity 5: 541-551. - doi: 10.1080/17550874.2012.74 0509

Connell JH (1978). Diversity in tropical rain forests and coral reefs - high diversity of trees and corals is maintained only in a non-equilibrium state. Science 199: 1302-1310. - doi: 10.1126/ science.199.4335.1302

Davies GM, Gray A (2015). Don't let spurious accusations of pseudoreplication limit our ability to learn from natural experiments (and other messy kinds of ecological monitoring). Ecology and Evolution 5: 5295-5304. - doi: 10.10 02/ece3.1782

Ente Parco Nazionale delle Dolomiti Bellunesi (2009). Piano di gestione del sito Natura 2000 SIC-ZPS IT3230083 Dolomiti Feltrine e Bellunesi [Management plan of the Natura 2000 site SCISPA IT3230083 Dolomites of Feltre and Belluno]. Ente Parco Nazionale delle Dolomiti Bellunesi, Feltre, Italy, pp. 321. [in Italian] [online] URL: http://www.dolomitipark.it/it/page.php?id $=343$

Esseen PA, Renhorn KE, Petersson RB (1996). Epiphytic lichen biomass in managed and oldgrowth boreal forests: Effect of branch quality. Ecological Applications 6: 228-238. - doi: 10.2307 12269566

Fattorini S, Dennis RLH, Cook LM (2011). Conserving organisms over large regions requires multi-taxa indicators: one taxon's diversityvacant area is another taxon's diversity zone. Biological Conservation 144: 1690-1701. - doi: 10.1016/j.biocon.2011.03.002

Fracasso G, Baccetti N, Serra L (2009). La lista CISO-COI degli uccelli italiani-Parte prima: liste $\mathrm{A}$, B e $\mathrm{C}$ [The list CISO-COI of the Italian birdsFirst part: lists A, B and C]. Avocetta 33: 5-24. [in Italian]

Gao T, Nielsen AB, Hedblom M (2015). Reviewing the strength of evidence of biodiversity indicators for forest ecosystems in Europe. Ecological Indicators 57: 420-434. - doi: 10.1016/j.ecolind.20 15.05 .028

Gil-Tena A, Saura S, Brotons L (2007). Effects of forest composition and structure on bird species richness in a Mediterranean context: implications for forest ecosystem management. Forest Ecology and Management 242: 470-476. doi: 10.1016/j.foreco.2007.01.080

Gioria M, Bacaro G, Feehan J (2011). Evaluating and interpreting cross-taxon congruence: potential pitfalls and solutions. Acta Oecologica 37: 187-194. - doi: 10.1016/j.actao.2011.02.001

Götmark F (2013). Habitat management alternatives for conservation forests in the temperate zone: review, synthesis, and implications. Forest Ecology and Management 306: 292-307. doi: 10.1016/j.foreco.2013.06.014

Grime JP (1973). Competitive exclusion in herbaceous vegetation. Nature 242: 344-347. - doi: $10.1038 / 242344 a 0$

Lasen C, Scariot A, Sitzia T (2008). Natura 2000 habitats map, forest types and vegetation outline of Val Tovanella Nature Reserve. In: "Research on the natural heritage of the reserves Vincheto di Celarda and Val Tovanella (Belluno province, Italy). Conservation of two protected areas in the context of a LIFE Project" (Hardersen S, Mason F, Viola F, Campedel D, Lasen C, Cassol $M$ eds). Arti Grafiche Fiorini, Verona, Italy, pp. 325-334.

Lawton JH, Bignell DE, Bolton B, Bloemers GF, Eggleton $P$, Hammond $P M$, Hodda $M$, Holt RD, Larsen TB, Mawdsley NA, Stork NE, Srivastava DS, Watt AD (1998). Biodiversity inventories, indicator taxa and effects of habitat modification in tropical forest. Nature 391: 72-76. - doi: 
$10.1038 / 34166$

Lazzarini A (1999). Amministrazione statale e boschi pubblici della montagna veneta nel primo Ottocento [State administration and public woodlands of the Veneto's mountains in the early 19th century]. Archivio Veneto 152: 45-85. [in Italian]

Lewandoski AS, Noss RF, Parsons DR (2010). The effectiveness of surrogate taxa for the representation of biodiversity. Conservation Biology 24: 1367-1377. - doi: 10.1111/j.1523-1739.2010.015 13.x

Mason F, Zapponi L (2015). The forest biodiversity artery: towards forest management for saproxylic conservation. iForest 9: 205-216. - doi: 10.3832/ifor1657-008

Nascimbene J, Dainese M, Sitzia T (2013). Contrasting responses of epiphytic and dead wooddwelling lichen diversity to forest management abandonment in silver fir mature woodlands. Forest Ecology and Management 289: 325-332. doi: 10.1016/j.foreco.2012.10.052

Nascimbene J, Fontana V, Spitale D (2014). A multi-taxon approach reveals the effect of management intensity on biodiversity in Alpine larch grasslands. Science of The Total Environment 487: 110-116. - doi: 10.1016/j.scitotenv.2014. 04.013

Neuhäuser M, Manly BFJ (2004). The Fisher-Pitman permutation test when testing for differences in mean and variance. Psychological Reports 94 (1): 189-194. - doi: 10.2466/pro.94.1.189194

Nimis PL, Martellos S (2003). A second checklist of the lichens of Italy with a thesaurus of synonyms. Monografia Museo Regionale di Scienze Naturali di Saint-Pierre, Val d'Aosta, Italy, vol. 4, pp. 192

Nordén B, Götmark F, Tönnberg $M$, Ryberg $M$ (2004). Dead wood in semi-natural temperate broadleaved woodland: contribution of coarse and fine dead wood, attached dead wood and stumps. Forest Ecology and Management 194: 235-248. - doi: 10.1016/j.foreco.2004.02.043

Oksanen J, Blanchet FG, Kindt R, Legendre P, Minchin PR, O'Hara RB, Simpson GL, Solymos P, Stevens MHH, Wagner H (2015). vegan: community ecology package. R package version 2.31. [online] URL: http://CRAN.R-project.org/pack age=vegan

Padovan F (2008). Checklist of the macromycetes of Val Tovanella Nature Reserve. In: "Research on the natural heritage of the reserves Vincheto di Celarda and Val Tovanella (Belluno province, Italy). Conservation of two protected areas in the context of a LIFE Project" (Hardersen S, Mason F, Viola F, Campedel D, Lasen C, Cassol M eds). Arti Grafiche Fiorini, Verona, Italy, pp. 363-376.

Paillet Y, Berges L, Hjalten J, Odor P, Avon C, Bernhardt-Römermann M, Bijlsma RJ, De Bruyn L, Fuhr M, Grandin U, Kanka R, Lundin L, Luque S, Magura T, Matesanz S, Meszaros I, Sebastia MT, Schmidt W, Standovar T, Tothmeresz B, Uotila A, Valladares F, Vellak K, Virtanen R (2010a). Biodiversity differences between managed and unmanaged forests: meta-analysis of species richness in Europe. Conservation Biology 24: 101-112. - doi: 10.1111/j.1523-1739.2009.013 99. $x$
Paillet Y, Berges L, Hjalten J, Odor P, Avon C, Bernhardt-Römermann M, Bijlsma RJ, De Bruyn L, Fuhr M, Grandin U, Kanka R, Lundin L, Luque S, Magura T, Matesanz S, Meszaros I, Sebastia MT, Schmidt W, Standovar T, Tothmeresz B, Uotila A, Valladares $F$, Vellak K, Virtanen R (2010b). Compromises in data selection in a meta-analysis of biodiversity in managed and unmanaged forests: response to Halme et al. Conservation Biology 24: 1157-1160. - doi: 10.1111/ j.1523-1739.2010.01543.x

Persiani AM, Lombardi F, Lunghini D, Granito VM, Tognetti R, Maggi O, Pioli S, Marchetti M (2015). Stand structure and deadwood amount influences saproxylic fungal biodiversity in Mediterranean mountain unmanaged forests. iForest 9: 115-124. - doi: 10.3832/ifor1304-008

Piussi P, Farrell EP (2000). Interactions between society and forest ecosystems: challenges for the near future. Forest Ecology and Management 132: 21-28. - doi: 10.1016/S0378-1127(00)0o 376-5

R Development Core Team (2015). R: a language and environment for statistical computing. $\mathrm{R}$ Foundation for Statistical Computing, Vienna, Austria. [online] URL: http://www.r-project.org/ Regione Veneto (2010). Database delle diverse litologie che compongono il territorio della Regione Veneto scala 1: 250.000 [Database of the various lithologies that make up the territory of the Veneto Region, scale 1:250.000]. Regione del Veneto - L. R. n. 28/76 - Formazione della Carta Tecnica Regionale. Regione Veneto, Venezia, Italy. [in Italian] [online] URL: http:// idt.regione.veneto.it/app/metacatalog/

Roberts MR, Gilliam FS (1995). Patterns and mechanisms of plant diversity in forested ecosystems: implications for forest management. Ecological Applications 5: 969-977. - doi: $10.2307 / 2269348$

Sabatini FM, Burrascano S, Azzella MM, Barbati A, De Paulis S, Di Santo D, Facioni L, Giuliarelli D, Lombardi F, Maggi O, Mattioli W, Parisi F, Persiani A, Ravera S, Blasi C (2016). One taxon does not fit all: herb-layer diversity and stand structural complexity are weak predictors of biodiversity in Fagus sylvatica forests. Ecological Indicators 69: 126-137. - doi: 10.1016/j.ecol ind.2016.04.012

Santi E, Maccherini S, Rocchini D, Bonini I, Brunialti G, Favilli L, Perini C, Pezzo F, Piazzini S, Rota E, Salerni E, Chiarucci A (2010). Simple to sample: vascular plants as surrogate group in a nature reserve. Journal for Nature Conservation 18: 2-11. - doi: 10.1016/j.jnc.2009.02.003

Seidling W, Travaglini D, Meyer P, Waldner P, Fischer R, Granke O, Chirici G, Corona P (2014). Dead wood and stand structure - relationships for forest plots across Europe. iForest 7: 269281. - doi: 10.3832/ifor1057-007

Sitzia T, Trentanovi G, Dainese M, Gobbo G, Lingua E, Sommacal M (2012). Stand structure and plant species diversity in managed and abandoned silver fir mature woodlands. Forest Ecology and Management 270: 232-238. - doi: 10.1016/j.foreco.2012.01.032

Sitzia T, Dainese M, Clementi T, Mattedi S (2014). Capturing cross-scalar variation of habitat selection with grid sampling: an example with hazel grouse (Tetrastes bonasia L.). European
Journal of Wildlife Research 60: 177-186. - doi: 10.1007/s10344-013-0762-3

Sitzia T, Campagnaro T, Gatti E, Sommacal M, Kotze DJ (2015). Wildlife conservation through forestry abandonment: responses of beetle communities to habitat change in the Eastern Alps. European Journal of Forest Research 134: 511-524. - doi: 10.1007/s10342-015-0868-0 Sitzia T, Campagnaro T, Grigolato S (2016). Ecological risk and accessibility analysis to assess the impact of roads under Habitats Directive. Journal of Environmental Planning and Management 59: 2251-2271. - doi: 10.1080/09640568. 2016.1140023

Susmel L (1958). Piano di riordinamento della proprietà silvo-pastorale Costantini di Val Tovanella (1958-1967) [Plan of reorganization of the Costantini forest and pasture property of Val Tovanella (1958-1967)]. Azienda di Stato per le Foreste Demaniali, Belluno, Italy, pp. 85. [in Italian]

Toigo M, Paillet Y, Noblecourt T, Soldati F, Gosselin F, Dauffy-Richard E (2013). Does forest management abandonment matter more than habitat characteristics for ground beetles? Biological Conservation 157: 215-224. - doi: 10.1016/j. biocon.2012.07.025

Torras O, Saura S (2008). Effects of silvicultural treatments on forest biodiversity indicators in the Mediterranean. Forest Ecology and Management 255: 3322-3330. - doi: 10.1016/j.foreco. 2008.02.013

Torsten H, Hornik K, Van De Wiel MA, Zeileis A (2008). Implementing a class of permutation tests: the coin package. Journal of Statistical Software 28: 1-23. [online] URL: http:// dare.ubvu.vu.nl/bitstream/handle/1871/27433/21 9692.pdf?sequence $=2$

Torsten H, Hornik K, Van De Wiel M, Zeileis A (2016). "coin": a computational framework for conditional inference. Web site. [online] URL: http://cran.r-project.org/web/packages/coin/vig nettes/coin.pdf

Vandekerkhove K, De Keersmaeker L, Menke N, Meyer P, Verschelde P (2009). When nature takes over from man: dead wood accumulation in previously managed oak and beech woodlands in North-western and Central Europe. Forest Ecology and Management 258: 425-435. - doi: 10.1016/j.foreco.2009.01.055

Vessby K, Soderstrom B, Glimskar A, Svensson B (2002). Species-richness correlations of six different taxa in Swedish seminatural grasslands. Conservation Biology 16: 430-439. - doi: 10.1046/j.1523-1739.2002.00198.x

Vizzarri M, Chiavetta U, Santopuoli G, Tonti D, Marchetti M (2015). Mapping forest ecosystem functions for landscape planning in a mountain Natura 2000 site, Central Italy. Journal of Environmental Planning and Management 58: 14541478. - doi: 10.1080/09640568.2014.931276

\section{Supplementary Material}

Tab. S1 - The original data used to perform the analysis and the geographical coordinates of each sampling plot.

Link: Sitzia_2181@supplo01.pdf 